\title{
The Contribution of Systematic Approaches to Characterizing the Proteins and Functions of the Endoplasmic Reticulum
}

\author{
Maya Schuldiner ${ }^{1}$ and Jonathan S. Weissman ${ }^{2}$ \\ ${ }^{1}$ Department of Molecular Genetics, Weizmann Institute of Science, Rehovot, Israel 76100 \\ ${ }^{2}$ Department of Cellular and Molecular Pharmacology, Howard Hughes Medical Institute, University \\ of California, San Francisco, California 94158 \\ Correspondence: maya.schuldiner@weizmann.ac.il
}

\begin{abstract}
The endoplasmic reticulum (ER) is a complex organelle responsible for a range of functions including protein folding and secretion, lipid biosynthesis, and ion homeostasis. Despite its central and essential roles in eukaryotic cells during development, growth, and disease, many ER proteins are poorly characterized. Moreover, the range of biochemical reactions that occur within the ER membranes, let alone how these different activities are coordinated, is not yet defined. In recent years, focused studies on specific ER functions have been complemented by systematic approaches and innovative technologies for high-throughput analysis of the location, levels, and biological impact of given components. This article focuses on the recent progress of these efforts, largely pioneered in the budding yeast Saccharomyces cerevisiae, and also addresses how future systematic studies can be geared to uncover the "dark matter" of uncharted ER functions.
\end{abstract}

$T^{1}$ he endoplasmic reticulum (ER) is a functionally and architecturally complex intracellular organelle. Bordered by a single continuous membrane, it surrounds the nucleus and stretches across the cytoplasm to the cell periphery, making intimate contact with other organelles along the way (Elbaz and Schuldiner 2011). The ER is perhaps best studied for its role as the entry point for proteins destined for the secretory pathway. After passing through or into the ER membrane, proteins fold and oligomerize, after which they are allowed to exit the ER and move onto their final cellular destination (Araki and Nagata 2011; Braakman and Bulleid 2011). Thus, the ER acts as a gatekeeper, ensuring that only properly folded proteins inhabit the rest of the secretory pathway while disposing of those polypeptides that fail to reach their native state (Ellgaard and Helenius 2003; Smith et al. 2011). In addition to this critical role in protein folding, quality control, and targeting, the ER is also responsible for a host of other cellular activities, including the synthesis of a wide range of cellular lipids (Sorger and Daum 2003; Vance 2003; Jakobsson et al. 2006; Fujita and Jigami 2008; Fagone and Jackowski 2009; Breslow and Weissman 2010; Gault et al. 2010) and regulation and homeostasis of $\mathrm{Ca}^{2+}$ (Sammels et al. 2010) and other ions. A dysfunctional or overfunctional ER had been shown to contribute to

Editors: Susan Ferro-Novick, Tom A. Rapoport, and Randy Schekman

Additional Perspectives on The Endoplasmic Reticulum available at www.cshperspectives.org

Copyright (C) 2013 Cold Spring Harbor Laboratory Press; all rights reserved; doi: 10.1101/cshperspect.a013284

Cite this article as Cold Spring Harb Perspect Biol 2013;5:a013284 
the progression of many diseases such as heart disease, neurodegeneration, and diabetes (Lin et al. 2008; Zhang and Kaufman 2008; Tabas and Ron 2011; Ozcan and Tabas 2012) and to affect the development of dedicated secretory cells such as plasma cells (Gass et al. 2004; Cenci and Sitia 2007) and insulin-secreting $\beta$-cells (Wagner and Moore 2011). Therefore, understanding how the spectrum of proteins, sugars, lipids, and ions, which together comprise the $\mathrm{ER}$, functions together to form a coherent organelle is of major importance in understanding the progression of, and thinking about potential therapies for, such diseases.

The first systematic attempt to uncover the repertoire of proteins required for a specific ER process was the isolation of "sec" mutants affecting protein secretion in the budding yeast Saccharomyces cerevisiae (Novick and Schekman 1979; Novick et al. 1980, 1981). These and related studies, together with parallel biochemical efforts in mammalian systems (Rothman and Orci 1992; Rothman 1994), formed the foundation for understanding the eukaryotic secretion machinery including defining the members of the translocon (Deshaies and Schekman 1987), the glycosylation machinery (Huffaker and Robbins 1982), the basic coat components of vesicular traffic (Barlowe et al. 1994), and the mediators of trafficking such as SNAREs (Sollner et al. 1993). The remarkable convergence between the yeast and mammalian studies also underscored the universal and conserved nature of the secretion machinery, highlighting the power of yeast as a model system for elucidating core aspects of ER function. This understanding has motivated the major systematic approaches that often rely on the pliability of budding yeast.

The yeast sec screens also inspired a range of conceptually related screens that defined the genes contributing to other key ER processes. Striking examples of such process-oriented screens include those used to delineate the entire enzymatic pathway responsible for glycosylphophatidylinositol (GPI) anchor formation (Inoue et al. 1993; Miyata et al. 1993; Takeda et al. 1993; Leidich et al. 1995a,b) and components responsible for ER-associated degradation (Hampton et al. 1996), as well as the syn- thesis and regulation of sterols (Lees et al. 1995), sphingolipids (Dickson 2008; Breslow 2013), and phospholipids (Henry et al. 2012).

Despite the remarkable success of these approaches, there are clear limitations to such process-focused strategies. Indeed, it has been more than three decades since the first sec screens and more than 15 years have passed since the publication of the yeast genome (Mewes et al. 1997), yet there remains a substantial fraction of the ER-localized proteins (roughly a quarter) that are largely or completely uncharacterized. And even for the genes to which a clear function has been assigned, it is difficult to know how many other distinct moonlighting jobs they might have. We know even less regarding how the various pathways are coordinated to allow the ER to function as a single holistic organelle. One of the great challenges of the postgenomic era is, therefore, to use novel methodologies to fill in these gaps in our knowledge, to uncover new processes, and to chart the interactions between the various ER functions.

Many of the studies on ER functions in the past have focused on process-centered approaches, in which one identifies and characterizes the key players that perform a specific cellular job. During the last decade, biology has gone through a technology-driven revolution with the development of high-throughput methods. The emergence of increasingly sophisticated functional genomic efforts that provide high-resolution and precise information on the location, levels, and biological impact of a given biological macromolecule (e.g., a specific protein, sugar, ion, or lipid species), now enable component-centered views that define systematically the functional roles of a given species without requiring a priori assumptions regarding the existing ER processes or gene functions. Such systematic approaches can therefore yield not only more data but also qualitatively better information as has been seen in areas such as genome sequencing, expression analysis, lipidomics, and now protein-protein interactions. Harnessing these systematic efforts toward the comprehensive exploration of more sophisticated cellular phenotypes should therefore not only speed up the rate of discovery but also 
help move cell biology toward more principled, less ad hoc approaches for defining gene functions. This article covers some of the major attempts at such efforts (Fig. 1), focusing predominantly on work performed in budding yeast.

\section{DEFINING THE ER PROTEOME}

A central goal of cell biology is to define the nature of subcellular structures and understand how these specialized structures contribute to cellular function. To achieve this, it is essential to catalog all of the proteins that reside in a given organelle such as the ER. A pioneering effort toward this goal was the creation of a collection of yeast strains into which a $\beta$-galactosidase tag was randomly inserted into the genome using transposon mutagenesis, enabling visual localization of fusion proteins by indirect immunofluorescence (Burns et al. 1994). Although these efforts yielded a very limited number of

\begin{tabular}{|c|c|c|}
\hline $\begin{array}{l}\text { Methods } \\
\text { - Microsome fractionation } \\
\text { followed by mass spectrometry } \\
\text { - Microscopy on tagged or } \\
\text { immunostained proteins }\end{array}$ & $\begin{array}{l}\text { Methods } \\
\text { - Affinity purification and mass } \\
\text { spectrometry of interacting proteins } \\
\text { - Yeast } 2 \text { hybrid and related protein } \\
\text { complementation strategies }\end{array}$ & $\begin{array}{l}\text { Methods } \\
\text { - Genetic screens on deletion, } \\
\text { overexpression, or mutant } \\
\text { libraries for specific defects } \\
\text { in ER function }\end{array}$ \\
\hline Contribution & Contribution & Contribution \\
\hline $\begin{array}{l}\text { - Define the complement of ER } \\
\text { proteins and their organization } \\
\text { - Understand how repertoire of } \\
\text { proteins changes in response to } \\
\text { mutations or stress }\end{array}$ & $\begin{array}{l}\text { - Define how ER proteins are arranged } \\
\text { into complexes } \\
\text { - Understand how complexes are } \\
\text { modulated in response to physiology }\end{array}$ & $\begin{array}{l}\text { - Decipher the biochemical role } \\
\text { of each ER protein } \\
\text { - Uncover novel ER functions } \\
\text { - Map the regulatory networks } \\
\text { of each process }\end{array}$ \\
\hline $\begin{array}{l}\text { Methods } \\
\text { - Lipidomics by mass } \\
\text { spectrometry } \\
\text { - In vivo reporters of lipid } \\
\text { levels and localization } \\
\text { Contribution } \\
\text { - Define distribution of } \\
\text { cellular lipids } \\
\text { - Understand function of } \\
\text { lipid signaling molecules } \\
\text { and regulation of lipid } \\
\text { composition }\end{array}$ & & $\begin{array}{l}\text { Methods } \\
\text { - Affinity purification and } \\
\text { mass spectrometry of } \\
\text { glycosylated proteins } \\
\text { - Glycan arrays } \\
\text { Contribution } \\
\text { - Define repertoire of } \\
\text { glycosylated proteins } \\
\text { - Understand effect } \\
\text { of glycosylation on } \\
\text { maturation, export, and } \\
\text { degradation }\end{array}$ \\
\hline $\begin{array}{l}\text { Methods } \\
\text { - In vivo reporters of } \\
\text { ion concentrations } \\
\text { - Ion analysis of microsomes }\end{array}$ & $\begin{array}{l}\text { Methods } \\
\text { - Quantitative analysis of } \\
\text { transcriptomes by } \\
\text { microarrays or RNA sequence }\end{array}$ & $\begin{array}{l}\text { Methods } \\
\text { - Creation of genetic } \\
\text { interaction maps } \\
\text { - Chemical profiling }\end{array}$ \\
\hline $\begin{array}{l}\text { Contribution } \\
\text { - Define the major mechanisms } \\
\text { of ion storage and homeostasis } \\
\text { - Understand coupling to other } \\
\text { key physiological events }\end{array}$ & $\begin{array}{l}\text { Contribution } \\
\text { - Define the transcriptional responses } \\
\text { governed by ER pathways } \\
\text { - Understand how the various ER } \\
\text { processes are regulated } \\
\text { - Identify novel cellular factors } \\
\text { important for ER function }\end{array}$ & $\begin{array}{l}\text { Contribution } \\
\text { - Define how ER proteins } \\
\text { are arranged into complexes } \\
\text { and pathways } \\
\text { - Understand the regulatory } \\
\text { networks of each process } \\
\text { - Uncover novel ER functions }\end{array}$ \\
\hline
\end{tabular}

Figure 1. Schematic representation of the various systematic approaches that could readily be used to explore ER functions. Each method can be used under a variety of conditions affecting ER functions such as stress, drugs, or mutations. 
predictions for new ER resident proteins, they highlighted the importance and feasibility of determining the subcellular localization of all yeast proteins.

Several key technical advances enabled the extension of the transposon studies. These included the development of GFP as a tool for monitoring protein localization in living cells (Tsien 1998), the sequencing of the yeast genome (Mewes et al. 1997), and the creation of efficient, PCR-based approaches for homologous recombination (Baudin et al. 1993). These advances made possible the creation of a systematic yeast library carrying fusions of the large majority of yeast open reading frames (ORFs) expressed from their endogenous genomic loci tagged with a green fluorescent protein (GFP) at their carboxyl termini (Huh et al. 2003). This library enabled the live imaging and determination of the subcellular localization of more than 4000 proteins, including slightly more than 300 in the ER. Surprisingly, 25\% of these proteins were completely uncharacterized, unnamed ORFs, and many more had only been described as having phenotypes in large-scale genetic screens. Moreover, the majority of ERlocalized proteins were not previously known to reside in this organelle. This approach also showed that the majority of ER proteins are transmembrane proteins and that the relatively limited number of fully soluble ER-resident proteins tend to be highly abundant chaperones (e.g., BiP, PDI, and calreticulin). A systematic study that analyzed the membrane orientation of more than 600 transmembrane proteins has now shed light on the topology of 120 of these ER proteins (Kim et al. 2006).

Related systematic GFP-fusion-based approaches have been completed in the fission yeast (Matsuyama et al. 2006; Hayashi et al. 2009) and are already being applied to other organisms (Reece-Hoyes et al. 2007). The attempts in mammalian cells are now relying either on a BAC-based recombineering approach that enables the production of defined GFP fusion proteins under control of their endogenous promoters (Poser et al. 2008) or on large-scale, indirect immunofluorescence with antibodies against native proteins, thus avoiding altogether the need to use fusion proteins (Uhlen et al 2010).

Major efforts are also being undertaken to refine the set of organelle resident proteins using mass spectrometry identification of native proteins on fractionated cells (Foster et al. 2006; Andreyev et al. 2010b). Efforts to specifically define the subset of ER proteins have used microsomes (biochemically purified ER fractions) from many different origins. It is difficult to determine whether the substantial discrepancies between different studies result from organism/tissue specificity or from technical issues (e.g., see mouse liver microsomes [Peng et al. 2012], canine pancreatic rough microsomes [Zahedi et al. 2009], mouse brain microsomes [Stevens et al. 2008], and rat liver microsomes [Gilchrist et al. 2006]). In parallel, computational efforts to define the set of ER proteins from published studies in humans have identified only 400 consensus residents (Scott et al. 2004). There is therefore clearly an immediate need for a concerted effort to synthesize the experimental data from microsomes with dedicated experiments aimed at obtaining a more complete picture of ER-resident proteins in mammalian cells. Although microsomes from a variety of mammalian tissues have been analyzed, similar studies in yeast are conspicuously absent. It will be important to combine GFP library- and fractionation-based efforts to obtain a truly comprehensive catalog of yeast ER and to monitor the dynamic remodeling of the ER under different physiological conditions. Such studies can also contribute, by homology, to defining the mammalian ER protein repertoire.

Although we are still far from having a welldefined map of ER proteins, the current lists already indicate that the complexity of functions residing within this organelle is far greater than previously appreciated and that much more work will be required to understand the range of ER processes. The localization studies also provided a powerful tool for efforts to systematically define ER function, allowing directed analysis of the few hundred genes localized to this organelle rather than open-ended searches. 


\section{CHARTING PROTEIN COMPLEXES IN THE ER}

In parallel to characterizing the ER proteome, it is essential to define the function and organization of all ER proteins. A key aspect of these efforts is the identification of physical interactions. In the past two decades, massive efforts have been dedicated to systematically mapping the repertoire of protein-protein interactions (PPIs) in cells using either protein complementation strategies such as yeast two-hybrid $(\mathrm{Y} 2 \mathrm{H})$ or pull-downs followed by mass spectrometry in a variety of organisms, including budding yeast (Ito et al. 2001; Gavin et al. 2002; Ho et al. 2002; Krogan et al. 2006; Yu et al. 2008), nematode ( $\mathrm{Li}$ et al. 2004), and fly (Giot et al. 2003; Guruharsha et al. 2011). This has been more challenging in mammals, and until now only partial data sets have been published, such as the signaling interactome (Bandyopadhyay et al. 2010), with many computational efforts being put forward to organize single interactions reported in the literature together with the emerging novel comprehensive data sets (Gandhi et al. 2006; Chaurasia et al. 2007). Unfortunately, none of these methodologies were well suited for the transmembrane ER proteins that do not maintain their normal interactions when localized to the nucleus, such as in $\mathrm{Y} 2 \mathrm{H}$ approaches, or that require specific protocols for extraction and digestion in pull-down-based techniques. This limitation has recently been addressed with a large-scale pull-down/mass spectrometry study, which focused on membrane proteins in yeast using a variety of detergent conditions optimized to keep membrane complexes intact (Babu et al. 2012).

Several approaches have been developed to overcome these intrinsic requirements and create an interactome for ER membrane proteins all of which rely on measuring the interactions in organello: one such approach is the split ubiquitin (Stagljar et al. 1998). This methodology was used, for example, to predict PPIs in the glycosylation complex (Yan et al. 2005), but never systematically used to predict all ER PPIs. Another approach is the split ire1 (Urech et al. 2003), used to create an interaction map of
ER chaperones and foldases (Jansen et al. 2012). However, the widest map that was recently created is based on a genome-wide dihydro folate reductase (DHFR) protein fragment complementation assay (Tarassov et al. 2008). It should be noted, however, that in all of these efforts, if the carboxyl termini of interacting proteins are on opposite sides of the membrane or if the tag causes mislocalization (obvious examples of ER proteins that would be mislocalized by carboxy-terminal tags are those carrying HDEL or KKXX retrieval motifs, Tail-anchored proteins, and GPI-anchored proteins) or rapid degradation of the protein, the assays will give rise to false negatives. Therefore, we are still far from a final description of the ER interactome. Finally, all interactomes until now were measured only under normal growth, and PPIs may change dramatically under different physiological conditions.

Many ER proteins have interactions not only with other proteins but also with lipids, sugars, and ions. These interactions may be as a result of binding to cofactors, as part of a sensing function, or due to an enzymatic role in transport or biogenesis of such small molecules. Knowing these additional physical interactions will shed much light on the function of such proteins. A first systematic attempt to map all proteinlipid interactions focused on 56 lipid species and measured their binding to 172 proteins (from lysates), uncovering 530 protein-lipid associations (Gallego et al. 2010). In principle, it is now also possible to assay the interaction of ER proteins with glycans using glycan arrays that already harbor more than 200 synthetic and natural glycan sequences that represent major glycan structures of glycoproteins and glycolipids (Blixt et al. 2004). However, this has not yet been done. There are currently no systematic approaches or attempts to measure protein-ion binding.

\section{ELUCIDATING THE SIGNAL TRANSDUCTION PATHWAYS OF ER STRESS}

The ER is embedded in a complex cellular milieu and is in constant communication with its 
environment. Thus, in addition to understanding the role of ER-resident proteins in this organelle's function, it is essential to determine how other cellular proteins communicate with and regulate this organelle. Gene expression studies can help achieve this goal by revealing how cells respond to defined perturbations in ER protein folding, lipid production, or ion homeostasis.

An early effort toward these goals examined the range of proteins regulated by the ER-specific stress pathway, termed the unfolded protein response (UPR) (Walter and Ron 2011). In yeast, the UPR is mediated by a simple signal transduction pathway comprising a sensor, IRE1 (Inositol Responsive Element1), and an executor, Hac1 (Homologous to Atf/Creb1). By specifically inducing ER protein misfolding in control yeast and in those deleted for Irel or Hac1, it was possible to define the full set of genes directly regulated by the UPR (Casagrande et al. 2000; Travers et al. 2000). These studies revealed that rather than regulating a limited set of ER-resident chaperones and phospholipid biosynthesis proteins, the UPR controls more than 400 genes, resulting in a large-scale remodeling of the ER and secretory pathway functions. Similar studies have since been extended to a variety of organisms (for a few examples, see human cell lines [Yoshida et al. 2003; Murray et al. 2004], plants [Martinez and Chrispeels 2003], Trypanosomes [Goldshmidt et al. 2010], and filamentous fungi [Guillemette et al. 2007]).

Although the Ire1 pathway is highly conserved from yeast to mammals, there exist two additional branches of the UPR in metazoans. The branches operate in parallel and use distinct mechanisms of signal transduction. Each branch is defined by a class of transmembrane ER-resident signaling components: IRE1, PERK (protein kinase RNA-like endoplasmic reticulum kinase), and ATF6 (activating transcription factor 6) (Mori 2009). As an extension to the early yeast expression studies, in metazoans it is possible to compromise specific branches of the UPR machinery, stress the ER, and study how each arm of the pathway contributes to sustaining the UPR. Such efforts have begun to define how the different UPR branches act in concert to provide a coherent and temporally coordinated response to ER stress (Wang et al. 1998; Okada et al. 2002; Lee et al. 2003; Blais et al. 2004; Shen et al. 2005). They have also defined a new function for Ire1 in cleavage and destabilization of a range of messages on the ER surface, a process termed Regulated Ire1 Dependent Decay (RIDD) (Hollien and Weissman 2006). Interestingly, recent studies in yeast have shown that although Ire1 is strongly activated during sporulation in yeast, only a subset of the previously defined UPR targets is turned on (Brar et al. 2012). Thus, it appears that even in budding yeast, rather than being a single monolithic response, the UPR can be tailored to the specific cellular needs. How this occurs remains to be discovered.

Similar transcriptional methods are also being used to uncover the output of other ERbased signaling pathways such as those regulating lipid composition and membrane dynamics (Jesch et al. 2006). Some well-studied examples are the unsaturated fatty acid signaling pathway of Spt23/Mga2 (that activate Ole1) (Hoppe et al. 2000; Auld et al. 2006); the phospholipid signaling pathway through Ino2, Ino4, and Opil (Santiago and Mamoun 2003; Loewen et al. 2004; Jesch et al. 2005); or the SREBP sterol regulatory pathway (Horton et al. 2003; Goldstein et al. 2006).

The above studies illustrate the value of defining the targets of specific ER signaling pathways. The next goals will be to better understand how these different responses function together in a coordinated manner, how the responses are modulated by the physiological state of a cell, and how they are used during non-stress responses such as differentiation of dedicated secretory cells.

\section{UNCOVERING THE FUNCTION OF ER PROTEINS}

Many of the proteins responsible for performing core ER functions were elucidated using genetic screens that rely on random mutagenesis and thus required that a very large number of colonies be screened to achieve high coverage. This changed with the emergence of systematic 
arrays of mutants in budding yeast (deletions [Giaever et al. 2002] or tunable/hypomorphic alleles [Mnaimneh et al. 2004; Breslow et al. 2008; Li et al. 2011]), Escherichia coli (Baba et al. 2006), and fission yeast (Kim et al. 2010), and synthesis of siRNA libraries against genes in multicellular invertebrates and vertebrates. These systematic platforms allowed the development of dedicated screens with analysis of complex phenotypes focusing on a limited number or subsets of mutants.

For example, screening based on visual phenotypes such as the degree of inheritance of the ER could only be achieved once a defined set of mutants was established (Du et al. 2001, 2004, 2006; Estrada de Martin et al. 2005; Loewen et al. 2007) and uncovered the first important proteins for this essential process. Another example is the immunostaining approach required to monitor the level of Kar2 secretion in all yeast mutants that described proteins required for ER folding, quality control, and retention (Copic et al. 2009). Finally, focusing on a finite set of mutants enabled creation of the yeast "ionome" map of the levels of 13 different ions on the background of every yeast deletion mutant (Eide et al. 2005); the map uncovered roles for several ER genes in modulating ion composition.

Using systematic approaches to modify yeast libraries (such as synthetic genetic arrays [SGA]) (Tong and Boone 2006; Cohen and Schuldiner 2011), it is possible to push these efforts forward through the creation of genetically tailored libraries of mutants and accurate measurements of complex phenotypes. For example, introduction of a reporter for activation of the UPR and accurate measurement of its activation by high-throughput flow cytometry in the deletion library enabled characterization of the entire set of genes required to maintain the folding capacity of the ER (Jonikas et al. 2009). Interestingly, the proteins whose loss conferred sensitivity to disruption of ER folding were in general different from those that were up-regulated during the UPR. Using appropriate reporters, it should be possible to monitor the effects of ER protein deletions on additional traits such as redox status (Merksamer et al. 2008), zinc levels (Qin et al. 2011), calcium stor-
Systematic Approaches to Characterize the ER

age (Tang et al. 2011), or pH (Miesenbock et al. 1998; Pineda Rodo et al. 2012).

By coupling systematic strain generation (e.g., crossing a GFP-marked reporter protein into a mutant library) with high-content screening approaches (Rimon and Schuldiner 2011), it is now possible to measure any cellular phenomena that can be visualized. For example, to better understand cargo selection into COPII vesicles, 11 tailored libraries were made by SGA. In each library, a specific GFP-labeled cargo protein destined to exit the ER was expressed in the background of either wild-type or one of 10 mutants in known cargo receptors. By microscopically tracking ER exit of the cargoes, it was possible to find the complement of ER proteins that depended on each of the known cargo receptors (Herzig et al. 2012). Such an approach could be used in the future to look for specificity in a wide variety of ER processes, such as which proteins use which translocation pathway, which folding pathways, and which degradation pathways.

Compared with yeast, the metazoan secretory pathway is less characterized and more complex. However, the first systematic screens using RNAi are starting to appear. For example, a genome-wide screen in a Drosophila cell line identified genes required for constitutive protein secretion using a plate reader to measure the levels of secreted horseradish peroxidase (HRP) (Bard et al. 2006). A similar screen performed in human cells assessed delivery of a fluorescently labeled transmembrane cargo protein to the cell surface (Simpson et al. 2012). Another approach to identify proteins required for proper folding and secretion was performed by identification of proteins that correct a mutation in the disease gene-cystic fibrosis transmembrane conductance regulator (CFTR) (Trzcinska-Daneluti et al. 2009).

\section{DEFINING ER FUNCTIONS THROUGH SYSTEMATIC GENETIC AND CHEMICAL INTERACTION MAPS}

In addition to a description of the molecular activity of individual proteins, a comprehensive description of a cell requires an understanding 
of how groups of proteins act together to perform specific biological processes and how those different processes communicate among themselves. Theoretical considerations suggest that information regarding these organizational levels can be obtained from the analysis of genetic interaction maps (pairwise descriptions of the extent to which the loss of one gene will aggravate or buffer the effect of the loss of a second one) (Breker and Schuldiner 2009).

Pioneering work in yeast provided the key enabling technology for the large-scale analysis of genetic interactions-the synthetic genetic array (SGA) (Tong et al. 2001, 2004). SGA made it possible to systematically construct pairwise double deletion mutants and then measure their phenotypes. In parallel, technologies have also arisen for measuring genetic interactions in a pooled format (Pan et al. 2007; Breker and Schuldiner 2009). For each gene in such maps, the spectrum of genetic interactions provides a high-resolution phenotype that can then be clustered to identify genes with common functions without requiring any a priori knowledge of what that activity is. In this manner, such functional maps overcome a key bias inherent in process-oriented screens: that is, the need to know ahead of time that a biological process exists. Although a focus on functional subsets of genes greatly simplifies the task of constructing genetic interaction maps (Collins et al. 2006), high-throughput approaches now enable the creation of massive genetic interaction maps that encompass a large fraction of all possible pairs in yeast (Costanzo et al. 2010).

An example of how analysis of a genetic interaction map can lead to a broad array of novel functional insights in ER pathways comes from follow-up work on predictions arising from a genetic interaction map of the yeast early secretory pathway (Schuldiner et al. 2005). Some of the major recent findings include the identification of Phs1 as the missing dehydratase in the pathway for very long chain fatty acid (VLCFA) biosynthesis. Uncovering the last protein in the pathway enabled a novel understanding of the principles by which structural diversity of VLCFAs is achieved (Denic and Weissman 2007). Another example is the identification of the GET pathway that is responsible for the recognition, targeting, and Sec61-independent insertion of tail-anchored membrane proteins (Schuldiner et al. 2008; Jonikas et al. 2009). Genetic interaction profiles also enable discovery of novel regulatory molecules such as the identification of the Orm proteins as critical mediators of sphingolipid homeostasis (Breslow et al. 2010). An example from a different genetic interaction map that focuses on both ER and mitochondrial proteins is the characterization of a role for the ER/mitochondrial tethering complex (Kornmann et al. 2009). Finally, recent studies of fission yeast genetic interaction maps have underscored the conservation and divergence of the UPR (Frost et al. 2012).

Although the initial studies focused on growth phenotypes as an output to measure genetic interactions, in principle, any quantitative phenotype can be used to create such maps. By using the level of activation of the UPR as a quantitative phenotype, a rich and informative genetic interaction map was created for mutants affecting folding in the ER (Jonikas et al. 2009). This both revealed novel functional relationship between known players and identified novel, uncharacterized factors that were critical for ER integrity. For example, clustering the deletion strains of this map allowed the identification of a novel and highly conserved ER membrane complex (EMC) that affects the proteostasis capacity of the ER in a general manner.

There recently have been efforts to create genetic interaction maps in additional organisms, including E. coli (Butland et al. 2008; Typas et al. 2008), fission yeast (Roguev et al. 2007), Drosophila (Horn et al. 2011), and nematodes (Lehner et al. 2006; Byrne et al. 2007; Fortunato 2009), but these have not been focused on ER functions.

A complementary approach to genetic interaction studies is the systematic analysis of chemical sensitivities in mutant libraries. Just as the pattern of genetic interaction provides a rich phenotype, the spectrum of chemical sensitivities can be used as a quantitative phenotype. Comparison of the chemical sensitivity pattern thus lets one identify genes of similar function that act in the same pathway or that 
form a physical complex. Creating large-scale chemical portraits in yeast has indeed enabled identification of protein complexes and pathways, some of which also reside in the ER (Hillenmeyer et al. 2008).

\section{FUTURE DIRECTIONS}

The use of systematic approaches is often technology driven and will most likely be so also in efforts for defining ER proteins and functions. To this end, there are several existing powerful technologies that could readily be applied to the study of ER functions. For example, lipidomic platforms exist that enable measurement of a large number of lipid species (Ejsing et al. 2009) in a cell or in microsomes (Andreyev et al. 2010a) even in high throughput. These platforms are only now starting to be used to systematically study the function of the ER and its proteins despite the fact that the ER is the major site of cellular lipid biosynthesis. Recent efforts that should be extended include looking at the effect of specific deletion strains on lipid composition of the cell (Ejsing et al. 2009; Guan et al. 2009; Aguilar et al. 2010) and studying regulation of biosynthesis under a variety of conditions (e.g., growth in inositol) (Gaspar et al. 2006). One of the reasons that lipidomics is still not used to its full power may be that small changes in extraction protocols, growth conditions, or strain maintenance give very large variability in the lipidome composition, and thus extra care is required and potentially novel computational tools will have to be created to enable comparison between laboratories and samples (Klose et al. 2012). However, in time, such powerful lipidomic approaches could be used to search for novel enzymes or regulatory factors involved in lipid biosynthesis as well as to understand the effect of a changing lipid environment on other ER functions (such as the levels of proteins and ions).

Systematic and robust strategies for glycomics are still not fully established because the structural analysis of glycans, which comprise different patterns of branching, various possible linkage positions as well as monomer anomericity, is technically difficult. However, existing technologies for mass spectrometrybased analysis of glycans (Morelle and Michalski 2007; Karlsson et al. 2009; Bereman and Muddiman 2011) can be used to assay how the repertoire of glycosylation states is affected in deletions of all ER proteins. In addition, novel methodologies of glycan arrays should be used for gathering information on glycan/protein interactions (Blixt et al. 2004).

More generally, platforms used successfully for the study of other cellular processes such as the systematic analysis of protein modifications (phosphorylation, ubiquitination, sumoylation, methylation, palmitoylation, etc.) have not before been used on purified microsomes to determine the repertoire of ER proteins undergoing such modifications. These can also be performed under specific stress conditions affecting ER function or on the background of mutants in various ER functions.

With each new experimental platform developed in both yeast and higher eukaryotes, it is becoming possible to assay more types of proteins, ions, lipids, and sugars, as well as the interactions between them, under more varied conditions and with increased accuracy. One of the major challenges will therefore be unifying these data (Fig. 1) into a set of testable hypotheses that will enable a true increase in our understanding of ER functions.

\section{ACKNOWLEDGMENTS}

We thank Tobias Walther and Christer Ejsing for fruitful discussions. M.S. is supported by an ERC StG 260395 grant and J.S.W. by the Howard Hughes Medical Institute and the National Institutes of Health.

\section{REFERENCES}

* Reference is also in this collection.

Aguilar PS, Frohlich F, Rehman M, Shales M, Ulitsky I, Olivera-Couto A, Braberg H, Shamir R, Walter P, Mann M, et al. 2010. A plasma-membrane E-MAP reveals links of the eisosome with sphingolipid metabolism and endosomal trafficking. Nat Struct Mol Biol 17: 901-908.

Andreyev AY, Fahy E, Guan Z, Kelly S, Li X, McDonald JG, Milne S, Myers D, Park H, Ryan A, et al. 2010a. Sub- 
M. Schuldiner and J.S. Weissman

cellular organelle lipidomics in TLR-4-activated macrophages. J Lipid Res 51: 2785-2797.

Andreyev AY, Shen Z, Guan Z, Ryan A, Fahy E, Subramaniam S, Raetz CR, Briggs S, Dennis EA. 2010b. Application of proteomic marker ensembles to subcellular organelle identification. Mol Cell Proteomics 9: 388-402.

Araki K, Nagata K. 2011. Protein folding and quality control in the ER. Cold Spring Harb Perspect Biol 3: a007526.

Auld KL, Brown CR, Casolari JM, Komili S, Silver PA. 2006. Genomic association of the proteasome demonstrates overlapping gene regulatory activity with transcription factor substrates. Mol Cell 21: 861-871.

Baba T, Ara T, Hasegawa M, Takai Y, Okumura Y, Baba M, Datsenko KA, Tomita M, Wanner BL, Mori H. 2006. Construction of Escherichia coli K-12 in-frame, singlegene knockout mutants: The Keio collection. Mol Syst Biol 2: 2006.0008.

Babu M, Vlasblom J, Pu S, Guo X, Graham C, Bean BD, Burston HE, Vizeacoumar FJ, Snider J, Phanse S, et al. 2012. Interaction landscape of membrane-protein complexes in Saccharomyces cerevisiae. Nature doi: 10.1038/ nature11354.

Bandyopadhyay S, Chiang CY, Srivastava J, Gersten M, White S, Bell R, Kurschner C, Martin CH, Smoot M, Sahasrabudhe S, et al. 2010. A human MAP kinase interactome. Nat Methods 7: 801-805.

Bard F, Casano L, Mallabiabarrena A, Wallace E, Saito K, Kitayama H, Guizzunti G, Hu Y, Wendler F, Dasgupta R, et al. 2006. Functional genomics reveals genes involved in protein secretion and Golgi organization. Nature 439: 604-607.

Barlowe C, Orci L, Yeung T, Hosobuchi M, Hamamoto S, Salama N, Rexach MF, Ravazzola M, Amherdt M, Schekman R. 1994. COPII: A membrane coat formed by Sec proteins that drive vesicle budding from the endoplasmic reticulum. Cell 77: 895-907.

Baudin A, Ozier-Kalogeropoulos O, Denouel A, Lacroute F, Cullin C. 1993. A simple and efficient method for direct gene deletion in Saccharomyces cerevisiae. Nucleic Acids Res 21: 3329-3330.

Bereman MS, Muddiman DC. 2011. N-linked global glycan profiling by nanoLC mass spectrometry. Methods $\mathrm{Mol}$ Biol 790: 87-97.

Blais JD, Filipenko V, Bi M, Harding HP, Ron D, Koumenis C, Wouters BG, Bell JC. 2004. Activating transcription factor 4 is translationally regulated by hypoxic stress. $\mathrm{Mol}$ Cell Biol 24: 7469-7482.

Blixt O, Head S, Mondala T, Scanlan C, Huflejt ME, Alvarez R, Bryan MC, Fazio F, Calarese D, Stevens J, et al. 2004. Printed covalent glycan array for ligand profiling of diverse glycan binding proteins. Proc Natl Acad Sci 101: 17033-17038.

Braakman I, Bulleid NJ. 2011. Protein folding and modification in the mammalian endoplasmic reticulum. Annu Rev Biochem 80: 71-99.

Brar GA, Yassour M, Friedman N, Regev A, Ingolia NT, Weissman JS. 2012. High-resolution view of the yeast meiotic program revealed by ribosome profiling. Science 335: $552-557$.
Breker M, Schuldiner M. 2009. Explorations in topologydelving underneath the surface of genetic interaction maps. Mol Biosyst 5: 1473-1481.

* Breslow DK. 2013. Sphingolipid homeostasis in the endoplasmic reticulum and beyond. Cold Spring Harb Perspect Biol doi: 10.1101/cshperspect.a013326.

Breslow DK, Weissman JS. 2010. Membranes in balance: Mechanisms of sphingolipid homeostasis. Mol Cell 40: 267-279.

Breslow DK, Cameron DM, Collins SR, Schuldiner M, Stewart-Ornstein J, Newman HW, Braun S, Madhani HD, Krogan NJ, Weissman JS. 2008. A comprehensive strategy enabling high-resolution functional analysis of the yeast genome. Nat Methods 5: 711-718.

Breslow DK, Collins SR, Bodenmiller B, Aebersold R, Simons K, Shevchenko A, Ejsing CS, Weissman JS. 2010. Orm family proteins mediate sphingolipid homeostasis. Nature 463: 1048-1053.

Burns N, Grimwade B, Ross-Macdonald PB, Choi EY, Finberg K, Roeder GS, Snyder M. 1994. Large-scale analysis of gene expression, protein localization, and gene disruption in Saccharomyces cerevisiae. Genes Dev 8: 1087-1105.

Butland G, Babu M, Diaz-Mejia JJ, Bohdana F, Phanse S, Gold B, Yang W, Li J, Gagarinova AG, Pogoutse O, et al. 2008. eSGA: E. coli synthetic genetic array analysis. Nat Methods 5: 789-795.

Byrne AB, Weirauch MT, Wong V, Koeva M, Dixon SJ, Stuart JM, Roy PJ. 2007. A global analysis of genetic interactions in Caenorhabditis elegans. J Biol 6: 8.

Casagrande R, Stern P, Diehn M, Shamu C, Osario M, Zuniga M, Brown PO, Ploegh H. 2000. Degradation of proteins from the ER of $S$. cerevisiae requires an intact unfolded protein response pathway. Mol Cell 5: 729-735.

Cenci S, Sitia R. 2007. Managing and exploiting stress in the antibody factory. FEBS Lett 581: 3652-3657.

Chaurasia G, Iqbal Y, Hanig C, Herzel H, Wanker EE, Futschik ME. 2007. UniHI: An entry gate to the human protein interactome. Nucleic Acids Res 35: D590-D594.

Cohen Y, Schuldiner M. 2011. Advanced methods for highthroughput microscopy screening of genetically modified yeast libraries. Methods Mol Biol 781: 127-159.

Collins SR, Schuldiner M, Krogan NJ, Weissman JS. 2006. A strategy for extracting and analyzing large-scale quantitative epistatic interaction data. Genome Biol 7: R63.

Copic A, Dorrington M, Pagant S, Barry J, Lee MC, Singh I, Hartman JL 4th, Miller EA. 2009. Genomewide analysis reveals novel pathways affecting endoplasmic reticulum homeostasis, protein modification and quality control. Genetics 182: 757-769.

Costanzo M, Baryshnikova A, Bellay J, Kim Y, Spear ED, Sevier CS, Ding H, Koh JL, Toufighi K, Mostafavi S, et al. 2010. The genetic landscape of a cell. Science 327: 425-431.

Denic V, Weissman JS. 2007. A molecular caliper mechanism for determining very long-chain fatty acid length. Cell 130: 663-677.

Deshaies RJ, Schekman R. 1987. A yeast mutant defective at an early stage in import of secretory protein precursors into the endoplasmic reticulum. J Cell Biol 105: 633-645. 
Dickson RC. 2008. Thematic Review Series: Sphingolipids. New insights into sphingolipid metabolism and function in budding yeast. J Lipid Res 49: 909-921.

Du Y, Pypaert M, Novick P, Ferro-Novick S. 2001. Auxlp/ Swa2p is required for cortical endoplasmic reticulum inheritance in Saccharomyces cerevisiae. Mol Biol Cell 12: 2614-2628.

Du Y, Ferro-Novick S, Novick P. 2004. Dynamics and inheritance of the endoplasmic reticulum. J Cell Sci 117: 28712878.

Du Y, Walker L, Novick P, Ferro-Novick S. 2006. Ptclp regulates cortical ER inheritance via Slt2p. EMBO J 25: 4413-4422.

Eide DJ, Clark S, Nair TM, Gehl M, Gribskov M, Guerinot ML, Harper JF. 2005. Characterization of the yeast ionome: A genome-wide analysis of nutrient mineral and trace element homeostasis in Saccharomyces cerevisiae. Genome Biol 6: R77.

Ejsing CS, Sampaio JL, Surendranath V, Duchoslav E, Ekroos K, Klemm RW, Simons K, Shevchenko A. 2009. Global analysis of the yeast lipidome by quantitative shotgun mass spectrometry. Proc Natl Acad Sci 106: 2136 2141.

Elbaz Y, Schuldiner M. 2011. Staying in touch: The molecular era of organelle contact sites. Trends Biochem Sci 36: 616-623.

Ellgaard L, Helenius A. 2003. Quality control in the endoplasmic reticulum. Nat Rev Mol Cell Biol 4: 181-191.

Estrada de Martin P, Du Y, Novick P, Ferro-Novick S. 2005. Ice2p is important for the distribution and structure of the cortical ER network in Saccharomyces cerevisiae. J Cell Sci 118: 65-77.

Fagone P, Jackowski S. 2009. Membrane phospholipid synthesis and endoplasmic reticulum function. J Lipid Res 50: S311-S316.

Fortunato A. 2009. Quantitative high-throughput analysis of synthetic genetic interactions in Caenorhabditis elegans by RNA interference. Genomics 93: 392-396.

Foster LJ, de Hoog CL, Zhang Y, Zhang Y, Xie X, Mootha VK, Mann M. 2006. A mammalian organelle map by protein correlation profiling. Cell 125: 187-199.

Frost A, Elgort MG, Brandman O, Ives C, Collins SR, MillerVedam L, Weibezahn J, Hein MY, Poser I, Mann M, et al. 2012. Functional repurposing revealed by comparing S. pombe and S. cerevisiae genetic interactions. Cell 149: 1339-1352.

Fujita M, Jigami Y. 2008. Lipid remodeling of GPI-anchored proteins and its function. Biochim Biophys Acta 1780: $410-420$.

Gallego O, Betts MJ, Gvozdenovic-Jeremic J, Maeda K, Matetzki C, Aguilar-Gurrieri C, Beltran-Alvarez P, Bonn S, Fernandez-Tornero C, Jensen LJ, et al. 2010. A systematic screen for protein-lipid interactions in Saccharomyces cerevisiae. Mol Syst Biol 6: 430.

Gandhi TK, Zhong J, Mathivanan S, Karthick L, Chandrika KN, Mohan SS, Sharma S, Pinkert S, Nagaraju S, Periaswamy B, et al. 2006. Analysis of the human protein interactome and comparison with yeast, worm and fly interaction datasets. Nat Genet 38: 285-293.

Gaspar ML, Aregullin MA, Jesch SA, Henry SA. 2006. Inositol induces a profound alteration in the pattern and rate
Systematic Approaches to Characterize the ER

of synthesis and turnover of membrane lipids in Saccharomyces cerevisiae. J Biol Chem 281: 22773-22785.

Gass JN, Gunn KE, Sriburi R, Brewer JW. 2004. Stressed-out $\mathrm{B}$ cells? Plasma-cell differentiation and the unfolded protein response. Trends Immunol 25: 17-24.

Gault CR, Obeid LM, Hannun YA. 2010. An overview of sphingolipid metabolism: From synthesis to breakdown. Adv Exp Med Biol 688: 1-23.

Gavin AC, Bosche M, Krause R, Grandi P, Marzioch M, Bauer A, Schultz J, Rick JM, Michon AM, Cruciat CM, et al. 2002. Functional organization of the yeast proteome by systematic analysis of protein complexes. Nature 415 : $141-147$.

Giaever G, Chu AM, Ni L, Connelly C, Riles L, Veronneau S, Dow S, Lucau-Danila A, Anderson K, Andre B, et al. 2002. Functional profiling of the Saccharomyces cerevisiae genome. Nature 418: 387-391.

Gilchrist A, Au CE, Hiding J, Bell AW, Fernandez-Rodriguez J, Lesimple S, Nagaya H, Roy L, Gosline SJ, Hallett M, et al. 2006. Quantitative proteomics analysis of the secretory pathway. Cell 127: 1265-1281.

Giot L, Bader JS, Brouwer C, Chaudhuri A, Kuang B, Li Y, Hao YL, Ooi CE, Godwin B, Vitols E, et al. 2003. A protein interaction map of Drosophila melanogaster. Science 302: 1727-1736.

Goldshmidt H, Matas D, Kabi A, Carmi S, Hope R, Michaeli S. 2010. Persistent ER stress induces the spliced leader RNA silencing pathway (SLS), leading to programmed cell death in Trypanosoma brucei. PLoS Pathog 6: e1000731.

Goldstein JL, DeBose-Boyd RA, Brown MS. 2006. Protein sensors for membrane sterols. Cell 124: 35-46.

Guan XL, Souza CM, Pichler H, Dewhurst G, Schaad O, Kajiwara K, Wakabayashi H, Ivanova T, Castillon GA, Piccolis M, et al. 2009. Functional interactions between sphingolipids and sterols in biological membranes regulating cell physiology. Mol Biol Cell 20: 2083-2095.

Guillemette T, van Peij NN, Goosen T, Lanthaler K, Robson GD, van den Hondel CA, Stam H, Archer DB. 2007. Genomic analysis of the secretion stress response in the enzyme-producing cell factory Aspergillus niger. BMC Genomics 8: 158.

Guruharsha KG, Rual JF, Zhai B, Mintseris J, Vaidya P, Vaidya N, Beekman C, Wong C, Rhee DY, Cenaj O, et al. 2011. A protein complex network of Drosophila melanogaster. Cell 147: 690-703.

Hampton RY, Gardner RG, Rine J. 1996. Role of $26 S$ proteasome and HRD genes in the degradation of 3-hydroxy-3-methylglutaryl-CoA reductase, an integral endoplasmic reticulum membrane protein. Mol Biol Cell 7: 2029-2044.

Hayashi A, Ding DQ, Tsutsumi C, Chikashige Y, Masuda H, Haraguchi T, Hiraoka Y. 2009. Localization of gene products using a chromosomally tagged GFP-fusion library in the fission yeast Schizosaccharomyces pombe. Genes Cells 14: $217-225$.

Henry SA, Kohlwein SD, Carman GM. 2012. Metabolism and regulation of glycerolipids in the yeast Saccharomyces cerevisiae. Genetics 190: 317-349.

Herzig Y, Sharpe HJ, Elbaz Y, Munro S, Schuldiner M. 2012. A systematic approach to pair secretory cargo receptors 
with their cargo suggests a mechanism for cargo selection by erv14. PLoS Biol 10: e1001329.

Hillenmeyer ME, Fung E, Wildenhain J, Pierce SE, Hoon S, Lee W, Proctor M, St Onge RP, Tyers M, Koller D, et al. 2008. The chemical genomic portrait of yeast: Uncovering a phenotype for all genes. Science 320: 362-365.

Ho Y, Gruhler A, Heilbut A, Bader GD, Moore L, Adams SL, Millar A, Taylor P, Bennett K, Boutilier K, et al. 2002. Systematic identification of protein complexes in Saccharomyces cerevisiae by mass spectrometry. Nature 415: $180-183$.

Hollien J, Weissman JS. 2006. Decay of endoplasmic reticulum-localized mRNAs during the unfolded protein response. Science 313: 104-107.

Hoppe T, Matuschewski K, Rape M, Schlenker S, Ulrich HD, Jentsch S. 2000. Activation of a membrane-bound transcription factor by regulated ubiquitin/proteasome-dependent processing. Cell 102: 577-586.

Horn T, Sandmann T, Fischer B, Axelsson E, Huber W, Boutros M. 2011. Mapping of signaling networks through synthetic genetic interaction analysis by RNAi. Nat Methods 8: $341-346$.

Horton JD, Shah NA, Warrington JA, Anderson NN, Park SW, Brown MS, Goldstein JL. 2003. Combined analysis of oligonucleotide microarray data from transgenic and knockout mice identifies direct SREBP target genes. Proc Natl Acad Sci 100: 12027-12032.

Huffaker TC, Robbins PW. 1982. Temperature-sensitive yeast mutants deficient in asparagine-linked glycosylation. J Biol Chem 257: 3203-3210.

Huh WK, Falvo JV, Gerke LC, Carroll AS, Howson RW, Weissman JS, O'Shea EK. 2003. Global analysis of protein localization in budding yeast. Nature 425: 686-691.

Inoue N, Kinoshita T, Orii T, Takeda J. 1993. Cloning of a human gene, PIG-F, a component of glycosylphosphatidylinositol anchor biosynthesis, by a novel expression cloning strategy. J Biol Chem 268: 6882-6885.

Ito T, Chiba T, Ozawa R, Yoshida M, Hattori M, Sakaki Y. 2001. A comprehensive two-hybrid analysis to explore the yeast protein interactome. Proc Natl Acad Sci 98: 4569-4574.

Jakobsson A, Westerberg R, Jacobsson A. 2006. Fatty acid elongases in mammals: Their regulation and roles in metabolism. Prog Lipid Res 45: 237-249.

Jansen G, Maattanen P, Denisov AY, Scarffe L, Schade B, Balghi H, Dejgaard K, Chen LY, Muller WJ, Gehring K, et al. 2012. An interaction map of ER chaperones and foldases. Mol Cell Proteomics (in press). doi: 10.1074/ mcp.M111.016550.

Jesch SA, Zhao X, Wells MT, Henry SA. 2005. Genome-wide analysis reveals inositol, not choline, as the major effector of Ino2p-Ino4p and unfolded protein response target gene expression in yeast. J Biol Chem 280: 9106-9118.

Jesch SA, Liu P, Zhao X, Wells MT, Henry SA. 2006. Multiple endoplasmic reticulum-to-nucleus signaling pathways coordinate phospholipid metabolism with gene expression by distinct mechanisms. J Biol Chem 281: 2407024083.

Jonikas MC, Collins SR, Denic V, Oh E, Quan EM, Schmid V, Weibezahn J, Schwappach B, Walter P, Weissman JS, et al. 2009. Comprehensive characterization of genes re- quired for protein folding in the endoplasmic reticulum. Science 323: 1693-1697.

Karlsson H, Larsson JM, Thomsson KA, Hard I, Backstrom M, Hansson GC. 2009. High-throughput and high-sensitivity nano-LC/MS and MS/MS for O-glycan profiling. Methods Mol Biol 534: 117-131.

Kim H, Melen K, Osterberg M, von Heijne G. 2006. A global topology map of the Saccharomyces cerevisiae membrane proteome. Proc Natl Acad Sci 103: 11142-11147.

Kim DU, Hayles J, Kim D, Wood V, Park HO, Won M, Yoo HS, Duhig T, Nam M, Palmer G, et al. 2010. Analysis of a genome-wide set of gene deletions in the fission yeast Schizosaccharomyces pombe. Nat Biotechnol 28: 617-623.

Klose C, Surma MA, Gerl MJ, Meyenhofer F, Shevchenko A, Simons K. 2012. Flexibility of a eukaryotic lipidomeInsights from yeast lipidomics. PLoS ONE 7: e35063.

Kornmann B, Currie E, Collins SR, Schuldiner M, Nunnari J, Weissman JS, Walter P. 2009. An ER-mitochondria tethering complex revealed by a synthetic biology screen. Science 325: 477-481.

Krogan NJ, Cagney G, Yu H, Zhong G, Guo X, Ignatchenko A, Li J, Pu S, Datta N, Tikuisis AP, et al. 2006. Global landscape of protein complexes in the yeast Saccharomyces cerevisiae. Nature 440: 637-643.

Lee AH, Iwakoshi NN, Glimcher LH. 2003. XBP-1 regulates a subset of endoplasmic reticulum resident chaperone genes in the unfolded protein response. Mol Cell Biol 23: 7448-7459.

Lees ND, Skaggs B, Kirsch DR, Bard M. 1995. Cloning of the late genes in the ergosterol biosynthetic pathway of Saccharomyces cerevisiae-A review. Lipids 30: 221-226.

Lehner B, Crombie C, Tischler J, Fortunato A, Fraser AG. 2006. Systematic mapping of genetic interactions in Caenorhabditis elegans identifies common modifiers of diverse signaling pathways. Nat Genet 38: 896-903.

Leidich SD, Drapp DA, Orlean P. 1995a. Isolation and characterization of yeast glycosylphosphatidylinositol anchoring mutants. Methods Enzymol 250: 560-571.

Leidich SD, Kostova Z, Latek RR, Costello LC, Drapp DA, Gray W, Fassler JS, Orlean P. 1995b. Temperature-sensitive yeast GPI anchoring mutants gpi2 and gpi3 are defective in the synthesis of $\mathrm{N}$-acetylglucosaminyl phosphatidylinositol. Cloning of the GPI2 gene. J Biol Chem 270: 13029-13035.

Li S, Armstrong CM, Bertin N, Ge H, Milstein S, Boxem M, Vidalain PO, Han JD, Chesneau A, Hao T, et al. 2004. A map of the interactome network of the metazoan C. elegans. Science 303: 540-543.

Li Z, Vizeacoumar FJ, Bahr S, Li J, Warringer J, Vizeacoumar FS, Min R, Vandersluis B, Bellay J, Devit M, et al. 2011. Systematic exploration of essential yeast gene function with temperature-sensitive mutants. Nat Biotechnol 29: 361-367.

Lin JH, Walter P, Yen TS. 2008. Endoplasmic reticulum stress in disease pathogenesis. Annu Rev Pathol 3: 399-425.

Loewen CJ, Gaspar ML, Jesch SA, Delon C, Ktistakis NT, Henry SA, Levine TP. 2004. Phospholipid metabolism regulated by a transcription factor sensing phosphatidic acid. Science 304: 1644-1647. 
Loewen CJ, Young BP, Tavassoli S, Levine TP. 2007. Inheritance of cortical ER in yeast is required for normal septin organization. J Cell Biol 179: 467-483.

Martinez IM, Chrispeels MJ. 2003. Genomic analysis of the unfolded protein response in Arabidopsis shows its connection to important cellular processes. Plant Cell 15: 561-576.

Matsuyama A, Arai R, Yashiroda Y, Shirai A, Kamata A, Sekido S, Kobayashi Y, Hashimoto A, Hamamoto M, Hiraoka Y, et al. 2006. ORFeome cloning and global analysis of protein localization in the fission yeast Schizosaccharomyces pombe. Nat Biotechnol 24: 841-847.

Merksamer PI, Trusina A, Papa FR. 2008. Real-time redox measurements during endoplasmic reticulum stress reveal interlinked protein folding functions. Cell 135: 933-947.

Mewes HW, Albermann K, Bahr M, Frishman D, Gleissner A, Hani J, Heumann K, Kleine K, Maierl A, Oliver SG, et al. 1997. Overview of the yeast genome. Nature 387: 7-65.

Miesenbock G, De Angelis DA, Rothman JE. 1998. Visualizing secretion and synaptic transmission with $\mathrm{pH}$-sensitive green fluorescent proteins. Nature 394: 192-195.

Miyata T, Takeda J, Iida Y, Yamada N, Inoue N, Takahashi M, Maeda K, Kitani T, Kinoshita T. 1993. The cloning of PIG$A$, a component in the early step of GPI-anchor biosynthesis. Science 259: 1318-1320.

Mnaimneh S, Davierwala AP, Haynes J, Moffat J, Peng WT, Zhang W, Yang X, Pootoolal J, Chua G, Lopez A, et al. 2004. Exploration of essential gene functions via titratable promoter alleles. Cell 118: 31-44.

Morelle W, Michalski JC. 2007. Analysis of protein glycosylation by mass spectrometry. Nat Protoc 2: 1585-1602.

Mori K. 2009. Signalling pathways in the unfolded protein response: Development from yeast to mammals. J Biochem 146: 743-750.

Murray JI, Whitfield ML, Trinklein ND, Myers RM, Brown PO, Botstein D. 2004. Diverse and specific gene expression responses to stresses in cultured human cells. Mol Biol Cell 15: 2361-2374.

Novick P, Schekman R. 1979. Secretion and cell-surface growth are blocked in a temperature-sensitive mutant of Saccharomyces cerevisiae. Proc Natl Acad Sci 76: $1858-1862$.

Novick P, Field C, Schekman R. 1980. Identification of 23 complementation groups required for post-translational events in the yeast secretory pathway. Cell 21: 205-215.

Novick P, Ferro S, Schekman R. 1981. Order of events in the yeast secretory pathway. Cell 25: 461-469.

Okada T, Yoshida H, Akazawa R, Negishi M, Mori K. 2002. Distinct roles of activating transcription factor 6 (ATF6) and double-stranded RNA-activated protein kinase-like endoplasmic reticulum kinase (PERK) in transcription during the mammalian unfolded protein response. Biochem J 366: 585-594.

Ozcan L, Tabas I. 2012. Role of endoplasmic reticulum stress in metabolic disease and other disorders. Annu Rev Med 63: $317-328$.

Pan X, Yuan DS, Ooi SL, Wang X, Sookhai-Mahadeo S, Meluh P, Boeke JD. 2007. dSLAM analysis of genome- wide genetic interactions in Saccharomyces cerevisiae. Methods 41: 206-221.

Peng F, Zhan X, Li MY, Fang F, Li G, Li C, Zhang PF, Chen Z. 2012. Proteomic and bioinformatics analyses of mouse liver microsomes. Int J Proteomics 2012: 832569.

Pineda Rodo A, Vachova L, Palkova Z. 2012. In vivo determination of organellar $\mathrm{pH}$ using a universal wavelengthbased confocal microscopy approach. PLOS ONE 7: e33229.

Poser I, Sarov M, Hutchins JR, Heriche JK, Toyoda Y, Pozniakovsky A, Weigl D, Nitzsche A, Hegemann B, Bird AW, et al. 2008. BAC TransgeneOmics: A highthroughput method for exploration of protein function in mammals. Nat Methods 5: 409-415.

Qin Y, Dittmer PJ, Park JG, Jansen KB, Palmer AE. 2011. Measuring steady-state and dynamic endoplasmic reticulum and Golgi $\mathrm{Zn}^{2+}$ with genetically encoded sensors. Proc Natl Acad Sci 108: 7351-7356.

Reece-Hoyes JS, Shingles J, Dupuy D, Grove CA, Walhout AJ, Vidal M, Hope IA. 2007. Insight into transcription factor gene duplication from Caenorhabditis elegans Promoterome-driven expression patterns. BMC Genomics 8: 27.

Rimon N, Schuldiner M. 2011. Getting the whole picture: Combining throughput with content in microscopy. J Cell Sci 124: 3743-3751.

Roguev A, Wiren M, Weissman JS, Krogan NJ. 2007. Highthroughput genetic interaction mapping in the fission yeast Schizosaccharomyces pombe. Nat Methods 4: 861866.

Rothman JE. 1994. Mechanisms of intracellular protein transport. Nature 372: 55-63.

Rothman JE, Orci L. 1992. Molecular dissection of the secretory pathway. Nature 355: 409-415.

Sammels E, Parys JB, Missiaen L, De Smedt H, Bultynck G. 2010. Intracellular $\mathrm{Ca}^{2+}$ storage in health and disease: $\mathrm{A}$ dynamic equilibrium. Cell Calcium 47: 297-314.

Santiago TC, Mamoun CB. 2003. Genome expression analysis in yeast reveals novel transcriptional regulation by inositol and choline and new regulatory functions for Opilp, Ino2p, and Ino4p. J Biol Chem 278: $38723-$ 38730.

Schuldiner M, Collins SR, Thompson NJ, Denic V, Bhamidipati A, Punna T, Ihmels J, Andrews B, Boone C, Greenblatt JF, et al. 2005. Exploration of the function and organization of the yeast early secretory pathway through an epistatic miniarray profile. Cell 123: 507-519.

Schuldiner M, Metz J, Schmid V, Denic V, Rakwalska M, Schmitt HD, Schwappach B, Weissman JS. 2008. The GET complex mediates insertion of tail-anchored proteins into the ER membrane. Cell 134: 634-645.

Scott M, Lu G, Hallett M, Thomas DY. 2004. The Hera database and its use in the characterization of endoplasmic reticulum proteins. Bioinformatics 20: 937-944.

Shen X, Ellis RE, Sakaki K, Kaufman RJ. 2005. Genetic interactions due to constitutive and inducible gene regulation mediated by the unfolded protein response in C. elegans. PLoS Genet 1: e37.

Simpson JC, Joggerst B, Laketa V, Verissimo F, Cetin C, Erfle H, Bexiga MG, Singan VR, Heriche JK, Neumann B, et al. 2012. Genome-wide RNAi screening 
identifies human proteins with a regulatory function in the early secretory pathway. Nat Cell Biol 14: 764-774.

Smith MH, Ploegh HL, Weissman JS. 2011. Road to ruin: Targeting proteins for degradation in the endoplasmic reticulum. Science 334: 1086-1090.

Sollner T, Whiteheart SW, Brunner M, ErdjumentBromage H, Geromanos S, Tempst P, Rothman JE. 1993. SNAP receptors implicated in vesicle targeting and fusion. Nature 362: 318-324.

Sorger D, Daum G. 2003. Triacylglycerol biosynthesis in yeast. Appl Microbiol Biotechnol 61: 289-299.

Stagljar I, Korostensky C, Johnsson N, te Heesen S. 1998. A genetic system based on split-ubiquitin for the analysis of interactions between membrane proteins in vivo. Proc Natl Acad Sci 95: 5187-5192.

Stevens SM Jr, Duncan RS, Koulen P, Prokai L. 2008. Proteomic analysis of mouse brain microsomes: identification and bioinformatic characterization of endoplasmic reticulum proteins in the mammalian central nervous system. J Proteome Res 7: 1046-1054.

Tabas I, Ron D. 2011. Integrating the mechanisms of apoptosis induced by endoplasmic reticulum stress. Nat Cell Biol 13: 184-190.

Takeda J, Miyata T, Kawagoe K, Iida Y, Endo Y, Fujita T, Takahashi M, Kitani T, Kinoshita T. 1993. Deficiency of the GPI anchor caused by a somatic mutation of the $P I G-A$ gene in paroxysmal nocturnal hemoglobinuria. Cell 73: 703-711.

Tang S, Wong HC, Wang ZM, Huang Y, Zou J, Zhuo Y, Pennati A, Gadda G, Delbono O, Yang JJ. 2011. Design and application of a class of sensors to monitor $\mathrm{Ca}^{2+}$ dynamics in high $\mathrm{Ca}^{2+}$ concentration cellular compartments. Proc Natl Acad Sci 108: 16265-16270.

Tarassov K, Messier V, Landry CR, Radinovic S, Serna Molina MM, Shames I, Malitskaya Y, Vogel J, Bussey H, Michnick SW. 2008. An in vivo map of the yeast protein interactome. Science 320: 1465-1470.

Tong AH, Boone C. 2006. Synthetic genetic array analysis in Saccharomyces cerevisiae. Methods Mol Biol 313: 171192.

Tong AH, Evangelista M, Parsons AB, Xu H, Bader GD, Page N, Robinson M, Raghibizadeh S, Hogue CW, Bussey H, et al. 2001. Systematic genetic analysis with ordered arrays of yeast deletion mutants. Science 294: 2364-2368.

Tong $\mathrm{AH}$, Lesage G, Bader GD, Ding H, Xu H, Xin X, Young J, Berriz GF, Brost RL, Chang M, et al. 2004. Global mapping of the yeast genetic interaction network. Science 303: $808-813$.

Travers KJ, Patil CK, Wodicka L, Lockhart DJ, Weissman JS, Walter P. 2000. Functional and genomic analyses reveal an essential coordination between the unfolded protein response and ER-associated degradation. Cell 101: 249258.
Trzcinska-Daneluti AM, Ly D, Huynh L, Jiang C, Fladd C, Rotin D. 2009. High-content functional screen to identify proteins that correct F508del-CFTR function. Mol Cell Proteomics 8: $780-790$.

Tsien RY. 1998. The green fluorescent protein. Annu Rev Biochem 67: 509-544.

Typas A, Nichols RJ, Siegele DA, Shales M, Collins SR, Lim B, Braberg H, Yamamoto N, Takeuchi R, Wanner BL, et al. 2008. High-throughput, quantitative analyses of genetic interactions in E. coli. Nat Methods 5: 781-787.

Uhlen M, Oksvold P, Fagerberg L, Lundberg E, Jonasson K, Forsberg M, Zwahlen M, Kampf C, Wester K, Hober S, et al. 2010. Towards a knowledge-based Human Protein Atlas. Nat Biotechnol 28: 1248-1250.

Urech DM, Lichtlen P, Barberis A. 2003. Cell growth selection system to detect extracellular and transmembrane protein interactions. Biochim Biophys Acta 1622: 117127.

Vance JE. 2003. Molecular and cell biology of phosphatidylserine and phosphatidylethanolamine metabolism. Prog Nucleic Acid Res Mol Biol 75: 69-111.

Wagner M, Moore DD. 2011. Endoplasmic reticulum stress and glucose homeostasis. Curr Opin Clin Nutr Metab Care 14: 367-373.

Walter P, Ron D. 2011. The unfolded protein response: From stress pathway to homeostatic regulation. Science 334: 1081-1086.

Wang XZ, Kuroda M, Sok J, Batchvarova N, Kimmel R, Chung P, Zinszner H, Ron D. 1998. Identification of novel stress-induced genes downstream of chop. $E M B O J 17$ : 3619-3630.

Yan A, Wu E, Lennarz WJ. 2005. Studies of yeast oligosaccharyl transferase subunits using the split-ubiquitin system: Topological features and in vivo interactions. Proc Natl Acad Sci 102: 7121-7126.

Yoshida H, Matsui T, Hosokawa N, Kaufman RJ, Nagata K, Mori K. 2003. A time-dependent phase shift in the mammalian unfolded protein response. Dev Cell 4: 265-271.

Yu H, Braun P, Yildirim MA, Lemmens I, Venkatesan K, Sahalie J, Hirozane-Kishikawa T, Gebreab F, Li N, Simonis N, et al. 2008. High-quality binary protein interaction map of the yeast interactome network. Science 322: $104-110$.

Zahedi RP, Volzing C, Schmitt A, Frien M, Jung M, Dudek J, Wortelkamp S, Sickmann A, Zimmermann R. 2009. Analysis of the membrane proteome of canine pancreatic rough microsomes identifies a novel Hsp40, termed ERj7. Proteomics 9: 3463-3473.

Zhang K, Kaufman RJ. 2008. From endoplasmic-reticulum stress to the inflammatory response. Nature 454: 455462. 


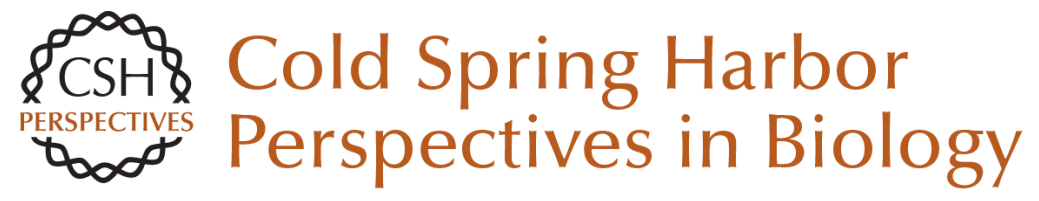

\title{
The Contribution of Systematic Approaches to Characterizing the Proteins and Functions of the Endoplasmic Reticulum
}

\author{
Maya Schuldiner and Jonathan S. Weissman
}

Cold Spring Harb Perspect Biol 2013; doi: 10.1101/cshperspect.a013284 originally published online January 28, 2013

\section{Subject Collection The Endoplasmic Reticulum}

Sorting and Export of Proteins at the Endoplasmic

Reticulum

Ishier Raote, Sonashree Saxena and Vivek Malhotra

Endoplasmic Reticulum Membrane Contact Sites, Lipid Transport, and Neurodegeneration Andrés Guillén-Samander and Pietro De Camilli

AMPylation and Endoplasmic Reticulum Protein Folding Homeostasis

Luke A. Perera and David Ron

The Endoplasmic Reticulum and the Fidelity of Nascent Protein Localization

Michael J. McKenna and Sichen Shao

Endoplasmic Reticulum Architecture and

Inter-Organelle Communication in Metabolic

Health and Disease

Ana Paula Arruda and Günes Parlakgül

Regulation and Functions of the ER-Associated Nrf1 Transcription Factor

Gary Ruvkun and Nicolas Lehrbach

Mechanism of Protein Translocation by the Sec61

Translocon Complex

Samuel Itskanov and Eunyong Park
Glycerolipid Synthesis and Lipid Droplet

Formation in the Endoplasmic Reticulum Robert V. Farese, Jr. and Tobias C. Walther

The Biogenesis of Multipass Membrane Proteins Luka Smalinskaite and Ramanujan S. Hegde

A TAle of Two Pathways: Tail-Anchored Protein Insertion at the Endoplasmic Reticulum Alina Guna, Masami Hazu, Giovani Pinton Tomaleri, et al.

Cholesterol Transport to the Endoplasmic Reticulum John P. Kennelly and Peter Tontonoz

The Role of the Rhomboid Superfamily in ER Protein Quality Control: From Mechanisms and Functions to Diseases Satarupa Bhaduri, Nicola A. Scott and Sonya E. Neal

ER-Phagy: Quality and Quantity Control of the Endoplasmic Reticulum by Autophagy Haruka Chino and Noboru Mizushima

Structure and Function of the Nuclear Pore Complex

Stefan Petrovic, George W. Mobbs, Christopher J. Bley, et al.

For additional articles in this collection, see http://cshperspectives.cshlp.org/cgi/collection/

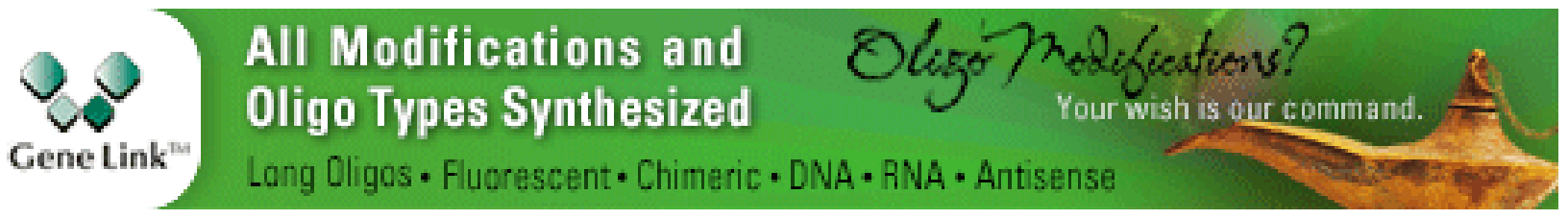




\section{Evolutionary Aspects of the Unfolded Protein Response \\ Kazutoshi Mori}

Post-Translational Regulation of HMG CoA Reductase

Youngah Jo and Russell A. DeBose-Boyd

For additional articles in this collection, see http://cshperspectives.cshlp.org/cgi/collection/

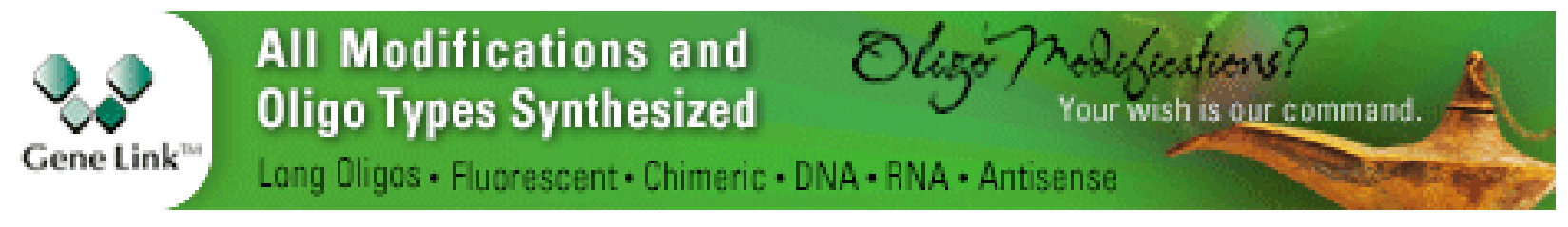

Copyright @ 2013 Cold Spring Harbor Laboratory Press; all rights reserved 